\title{
Analisis Teknis dan Ekonomis Penerapan Lampu Penerangan Jalan Umum Panel Surya di Kota Sukabumi
}

\section{Techno-economic Analysis of The Public Street Light with Solar Cell Power Implementation in Sukabumi City}

Dion Sanaha ${ }^{\mathrm{a}}$, Irzaman ${ }^{\mathrm{b}}$, Sri Mulatsih ${ }^{\mathrm{a}}$

a Sekolah Pascasarjana, Institut Pertanian Bogor, Jl. Raya Dramaga Bogor 16680, Indonesia

${ }^{\mathrm{b}}$ Program Studi Pengelolaan Sumber Daya Alam dan Lingkungan, Sekolah Pascasarjana, Institut Pertanian Bogor, Kampus IPB Darmaga Bogor, 16680, Indonesia

${ }^{c}$ Program Studi Pengelolaan Sumber Daya Alam dan Lingkungan, Sekolah Pascasarjana, Institut Pertanian Bogor, Kampus IPB Darmaga Bogor, 16680, Indonesia

\section{Article Info:}

Received: 03 - 10 - 2018

Accepted: 05 - 09 - 2019

Keywords:

Batteres, LED, NPV, sollar cell, PSL.

Corresponding Author:

Dion Sanaha

Sekolah Pascasarjana, Institut

Pertanian Bogor;

Email: d_sanaha@yahoo.com.

How to cite (CSE Style $8^{\text {th }}$ Edition):

Sanaha D, Irzaman, Mulatsih S. 2020. Analisis teknis dan ekonomis penerapan lampu penerangan jalan umum panel surya di Kota Sukabumi. 10(1): 77-88. http://dx.doi.org/10.29244/jpsl.10.1. 77-88.
Abstract. Public Street Light (PSL) with Solar Cell Power has good prospects to be developed in the equator. PSL design must provide reliable service. The aims of tAhis research are to know how the design of PSL with Solar Cell Power can provide a reliable service of The PSL. Besides that, monitoring of the performance of PSL is expected to be carried out centrally, this is to facilitate employees in observing the performance of the lights, also to anticipate damage PSL components. The design of PSL are expected to meet these expectations. This PSL designed can provide data on the performance of the main components of the PSL with Solar Cell Power, namely: Solar Cell, and economic feasibility analysis to PSL economically. Solar panels and lights work according to the technival spesifications, while the battery does not work according to technical spesifications, when the light is on less than specified, which is less than 12 hours. Economic analysis is taken into account of the design of this PSL. Net Present Value (NPV) are used in analyzing the Smart Design of PSL, which is by adding up all cash flow and investment costs. PSL is not an economics investment project carried out by the private sector. NPV Value with $10 \%$ discount rate indicates that PSL is not feasible for business. Calculation of 0\% discount rate, economic analysis is obtained if the price of electricity per KWH reaches of value of Rp. 11 027, which is more than seven times the price of PLN electricity per KWH without subsidies. Batteries and LEDs. Descriptive analysis is used to analyze PSL technically,

\section{PENDAHULUAN}

Lampu Penerangan Jalan Umum (PJU) di Kota Sukabumi, berdasarkan sumber daya listriknya, dibagi dalam dua jenis, yaitu: lampu PJU yang bersumber dari daya listrik yang dihasilkan oleh Perusahaan Listrik Negara (PLN) dan yang bersumber dari cahaya matahari melalui daya listrik yang dihasilkan oleh panel surya atau cahaya matahari. 
Penggunaan Lampu PJU bersumber dari cahaya matahari memiliki prospek yang baik mengingat ketersediannya energinya yang berlimpah dan terus menerus karena posisi Indonesia di Kawasan tropis yang mendapatkan cahaya matahari sepanjang tahun. Potensi inilah yang dilihat Kota Sukabumi sebagai peluang untuk memanfaatkan energi yang besar ini sebagai sumber cahaya penerangan jalan. Kehandalan layanan lampu PJU juga merupakan faktor yang perlu diperhatikan. Lampu PJU diperlukan terutama pada malam hari dimana jika terdapat gangguan listrik oleh PLN yang berdampak pada pemadaman, maka lampu PJU harus tetap menyala.

Pemantauan teknis kinerja lampu diharapkan dapat dilakukan secara terpusat. Jumlah titik lampu yang banyak dan terus bertambah memerlukan desain lampu PJU yang memungkinkan pemantauan secara menyeluruh terhadap keadaan lampu PJU yang ada. Sistem pemantauan terkait lampu diharapkan dapat dilakukan dari suatu lokasi tertentu yang memberikan data dan informasi teknis mengenai kondisi lampu PJU terpasang, sehingga memudahkan monitoring dan membuat kegiatan pemeliharaan lebih efisien dan mempermudah perawatan.

Selain secara teknis, perlu dilakukan analisis secara ekonomis mengenai desain yang akan dikembangkan. Analisis ekonomis yang digunakan adalah dengan menghitung kelayakan investasi. Selanjutnya Gambar 1 menyampaikan kerangka pemikiran dari penelitian yang dilakukan.

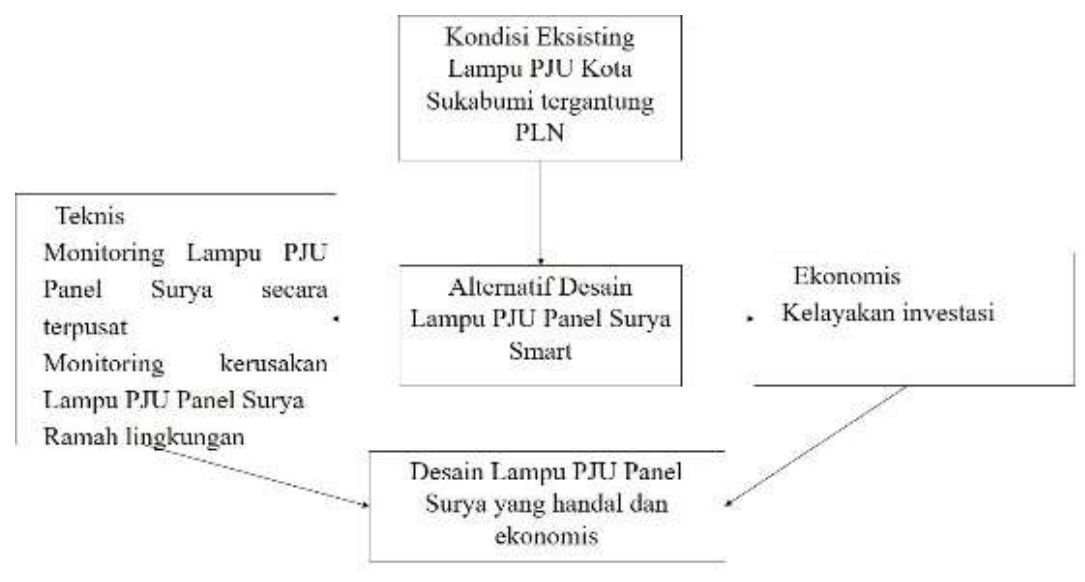

Gambar 1 Kerangka Pemikiran.

Kondisi eksisting Lampu PJU di Kota Sukabumi yang masih tergantung pada listrik PLN menyebabkan adanya pemikiran untuk melakukan alternatif Lampu PJU Panel Surya. Secara teknis Lampu PJU Panel Surya ini harus dapat memonitoring status Lampu PJU, keadaan komponennya dan ramah lingkungan. Selain secara teknis, lampu PJU Panel Surya juga dievaluasi kelayaannya secara ekonomis.

\section{METODE}

\section{Lokasi dan Waktu Penelitian}

Penelitian ini dilaksanalan pada periode Juli 2018 sampai dengan September 2018 di 11 titik lokasi di Jalan Merdeka Kelurahan Cikundul Kota Sukabumi, Provinsi Jawa Barat. Data yang digunakan dalam penelitian ini meliputi data primer dan data sekunder. Data primer merupakan data yang didapat dari hasil pengukuran langsung peralatan terpasang, sedangkan data sekunder merupakan data pendukung yang didapat dari sumber-sumber lain. Rangkaian peralatan yang digunakan dalam penelitian ini adalah lampu LED, panel surya, baterai lithium, Solar Charge Controller (SCC), Smart Controller Module (SCM), dan Gateway. 


\section{Lampu LED}

Lampu LED atau kepanjangannya Light Emitting Diode awalnya adalah suatu lampu yang digunakan sebagai indikator dalam perangkat elektronika, yang biasanya memiliki fungsi untuk menunjukkan status dari perangkat elektronika tersebut. Lampu ini sangat popular untuk lampu indikator yang memiliki lumens kecil. Pada perkembangannya lampu LED yang memiliki lumens lebih besar, sehingga popular dipakai untuk penerangan area yang lebih luas seperti penerangan ruangan atau bahkan penerangan jalan umum.

Lampu LED banyak di pilih untuk digunakan sebagai Penerangan Jalan umum dikarenakan daya yang digunakan oleh lampu LED ini lebih sedikit dibandingkan oleh lampu jenis lainnya. Spesifikasi Lampu LED yang digunakan untuk penerangan jalan umum berbeda dengan yang dipakai untuk area penerangan ruangan, karena cakupan pencahayaan penerangan jalan umum ini sangatlah luas di bandingan dengan penerangan ruangan. Lampu LED yang digunakan pada penelitian ini adalah Lampu LED bermerk Solarens, tipe SL0202MT yang memiliki spesifikasi teknis:

$\begin{array}{ll}\text { Rated Power }( \pm 10 \%) & : 40 \mathrm{~W} \text { DC } \\ \text { Rated Fluks }(\mathrm{lm}) & : 6480 \\ \text { System Efficacy }(\mathrm{lm} / \mathrm{W}) & : 162 \\ \text { Input Voltage } & : 12 / 24 \mathrm{VDC} \\ \text { Power Factor } & : 0.91 \\ \text { Harga } & : \text { Rp. } 3440000\end{array}$

\section{Panel Surya}

Panel Surya merupakan satu peralatan yang digunakan untuk menyediakan sumber daya pada lampu penerangan jalan umum. Pada penelitian ini, penggunaan panel surya terutama dengan pertimbangan bahwa lokasi penelitian berada di daerah khatulistiwa dimana ketersedian cahaya matahari tersedia sepanjang tahun sebagai sumber energy yang tersedia secara gratis untuk jangka waktu yang sangat lama. Selain itu, pertimbangan bahwa pelayanan lampu penerangan jalan umum pada malam hari tidak boleh terhenti jika terjadi pemadaman akibat gangguan listrik PLN.

Prinsip kerja dari surya panel adalah mengubah energi radiasi surya menjadi arus listrik searah dengan menggunakan lapisan-lapisan tipis dari silicon $(\mathrm{Si})$ murni atau bahan semikonduktor lainnya. Pada saat ini silicon merupakan bahan yang terbanyak dipakai. Silikon merupakan suatu unsur yang banyak terdapat di alam. Untuk pemakaian sebagai semikonduktor, silicon harus dimurnikan hingga suatu tingkat pemurnian yang tinggi sekali: kurang dari satu atom pengotoran per $10^{10}$ atom silicon.Panel Surya yang digunakan pada penelitian ini adalah Panel Surya bermerk Jembo PV, tipe 150P yang memiliki spesifikasi teknis:

$\begin{array}{llll}\text { Max Power } & : 150 \mathrm{WP} & \text { Max Power Point Voltage } & : 18.68 \mathrm{Vmpp} \\ \text { Power Output Tolerance } & : 3 \% & \text { Max Power Point Current } & : 8.06 \mathrm{Ampp} \\ \text { Modul Efficiency } & : 15.13 \% & \text { Cell Type } & : \text { Polycristaline } \\ & & \text { Harga } & : \text { Rp. } 2490000\end{array}$

\section{Baterai Lithium}

Baterai ion lithium (biasa disebut Baterai Li-ion atau LIB) adalah salah satu jenis baterai isi ulang (rechargable battery). Pada penelitian ini, baterai digunakan untuk menyimpan daya listrik yang dihasilkan dari panel surya pada saat siang hari, dan menyediakan daya listrik untuk menyalakan lampu LED pada malam hari. Baterai lithium yang digunakan adalah baterai yang dapat diisi ulang. Di dalam baterai ini, ion lithium bergerak dari elektroda negatif ke elektroda positif saat dilepaskan, dan kembali saat diisi ulang. Baterai lithium yang digunakan pada penelitian ini adalah Baterai lithium bermerk JYC, tipe LFPxx yang memiliki spesifikasi teknis: 
Nominal Voltage : 12.8V

Nominal Capacity: $50 \mathrm{Ah}$

Energy $\quad: 640 \mathrm{Wh}$
Cycle life : >2000 cycles @1C 100\%DOD

Harga : :Rp. 6037500

\section{Solar Control Charge(SCC)}

Solar Charge Controller (SCC) adalah salah satu komponen pendukung yang sangat penting dalam Sistem Lampu PJU panel surya. Alat ini berfungsi untuk mengatur proses pengisian (charging) dan pemakaian baterai (discharging). Alat ini juga digunakan untuk menjaga baterai supaya tidak mudah rusak, dengan memutus arus baterai jika pengisian baterai sudah terisi penuh dan juga memutus beban/lampu jika baterai sudah habis. SCC yang digunakan memiliki fasilitas yang sangat membantu kinerja panel surya dan baterai lithium, dengan fasilitas sebagai berikut sun switch, berguna bagi sistem kerja dari panel surya dan juga baterai lithium, karena fasilitas ini dapat mengatur kinerja dari lampu LED penerangan jalan umum, serta system proteksi yang memiliki fungsi untuk pengamanan instalasi terhadap kemungkinan terjadinya hubungan singkat arus lalu lintas yang berakibat fatal akibat beberapa hal seperti pemasangan kabel positif dan negatif ke terminal input panel surya terbalik/salah, atau jika pemasangan kabel positif \& negatif ke terminal input baterai terbalik/salah. SCC yang digunakan pada penelitian ini adalah SCC bermerk Epever, tipe 5210 BPL dengan harga Rp. 3330000.

\section{Smart Controller Module (SCM)}

Komponen penting dari desain Lampu PJU panel surya Smart ini adalah Smart Controller Module (SCM). Alat ini terhubung dengan $S C C$, dan gateway, Fungsi dari SCM ini adalah menerima data dari $S C C$ yang kemudian mengirimkan data tersebut ke Gateway melalui frekuensi radio. Setiap SCM memiliki alamat (IP Adress) yang berbeda sehingga Gateway dapat mengenali data yang dikirim oleh masing-masing SCM. SCM yang dipergunakan pada penelitian ini adalah merk Epever model eBox tipe WL-433M-01dengan harga Rp. 2990000.

\section{Gateway}

Gateway (Gerbang Jaringan) adalah suatu perangkat yang menghubungkan jaringan komputer yang satu atau lebih jaringan komputer dengan media komunikasi yang berbeda. Pada sistem ini, Gateway digunakan dalam pengumpulan dan pengolahan data lampu PJU panel surya melalui Web-Server, sehingga dapat melakukan monitoring secara berkala terhadap masing - masing unit Lampu PJU panel surya dengan memberikan informasi / data yang diperlukan. Pada penelitian ini, gateway terhubung dengan server epever melalui jaringan internet GSM Telkomsel. Gateway yang digunakan pada penelitian ini adalah merk Epever, tipe Ebox-CIWL-01 Concentrator dengan harga Rp. 3120000.

\section{Metode Pengumpulan Data}

Data teknis diambil dari PJU panel surya hasil desain, adapun sumber data teknis diambil dari 11 titik lampu PJU di Jalan Cikundul Kota Sukabumi, pengambilan data dilakukan dari aplikasi Smart PJU yang dibuat oleh Epever selama 7 hari yaitu tanggal 20-26 September 2018. Hal ini juga disertai pengamatan di lokasi. Data teknis ini memuat tentang kondisi lampu dan kondisi komponen yang diambil dari monitoring data di komputer.

\section{Metode Analisis Data}

Analisis yang digunakan dalam penelitian ini adalah analisis deskriptif yang merupakan analisis teknis dari rangkaian sistem penerangan jalan yang dibuat dan analisis kelayakan ekonomis. Analisis deskriptif dilakukan untuk mendeskripsikan teknis dalam bentuk tabulasi data rata-rata arus dan tegangan dari komponen 
lampu PJU. Analisis teknis dilakukan dengan membaca data yang ditampilkan pada Komputer PC/Laptop. Data-data yang diperoleh adalah 1) Status Lampu LED, 2) Status baterai, dan 3) Status solar panel.

Analisa kelayakan ekonomis menggunakan indikator $N P V$ dan IRR dari cash flow yang berupa biaya investasi dan biaya operasional serta penerimaan. Data investasi diperoleh dari harga e-katalog, harga on-line dan hasil lelang pada layanan pengadaan secara elektronik Jawa Barat, data operasional diperoleh dari data primer berdasarkan hasil pengamatan di lapangan, dan data penerimaan diperoleh dari data primer pengukuran daya panel surya dan harga yang dihasilkan yaitu harga kwh dari PLN tanpa subsidi. Harga sistem Lampu PJU panel surya Smart diperoleh dari harga-harga pembelian komponennya. Dari harga tersebut dilakukan perhitungan analisis mengenai kelayakan ekonomis sistem tersebut.

Nilai Net Present Value (NPV) yang dihitung merupakan selisih antara pengeluaran dan pemasukan yang telah didiskon dengan menggunakan social opportunity cost of capital sebagai diskon faktor, atau dengan kata lain merupakan arus kas yang diperkirakan pada masa yang akan datang yang didiskontokan pada saat ini. Untuk menghitung NPV diperlukan data tentang perkiraan biaya investasi, biaya operasi, dan pemeliharaan serta perkiraan manfaat/benefit dari proyek yang direncanakan. Jadi perhitungan NPV mengandalkan pada teknik arus kas yang didiskontokan.

Analisa kelayakan ekonomis menggunakan indikator NVP dan IRR dari cash flow yang berupa biaya investasi dan biaya operasional serta penerimaan. Data investasi diperoleh dari harga e-katalog, harga on-line dan hasil lelang pada layanan pengadaan secara elektronik Jawa Barat, data operasional diperoleh dari data primer berdasarkan hasil pengamatan di lapangan, dan data penerimaan diperoleh dari data primer pengukuran daya panel surya dan harga yang dihasilkan yaitu harga kwh dari PLN tanpa subsidi.

Harga sistem Lampu PJU panel surya Smart diperoleh dari harga-harga pembelian komponennya. Dari harga tersebut dilakukan perhitungan analisis mengenai kelayakan ekonomis sistem tersebut.

Net Present Value (NPV) merupakan selisih antara pengeluaran dan pemasukan yang telah didiskon dengan menggunakan social opportunity cost of capital sebagai diskon faktor, atau dengan kata lain merupakan arus kas yang diperkirakan pada masa yang akan datang yang didiskontokan pada saat ini. Untuk menghitung NPV diperlukan data tentang perkiraan biaya investasi, biaya operasi, dan pemeliharaan serta perkiraan manfaat/benefit dari proyek yang direncanakan. Jadi perhitungan NPV mengandalkan pada teknik arus kas yang didiskontokan.

Menurut Kasmir (2003) NPV atau nilai bersih sekarang merupakan perbandingan antara Present Value (PV) kas bersih dengan PV investasi selama umur investasi. Sedangkan menurut Ibrahim (2003) NPV merupakan net benefityang telah didiskon dengan menggunakan social opportunity cost of capital (SOCC) sebagai discount factor. Arus kas masuk dan keluar yang didiskontokan pada saat ini atau Present Value (PV) yang dijumlahkan selama masa hidup dari proyek tersebut dapat dihitung dengan rumus:

$$
\operatorname{PVr}=\operatorname{Rt} /(1+\mathrm{i})^{\mathrm{t}}
$$

Rumus di atas digunakan saat proyek dijalankan dalam jangka waktu yang panjang, dimana :

$\mathrm{PVr}=$ Present Value dari revenue

$\mathrm{Rt} \quad=$ Arus kas bersih (the net cash flow) dalam waktu $\mathrm{t}$

$\mathrm{i} \quad=$ Suatu bunga diskonto yang digunakan

$\mathrm{t} \quad=$ Waktu arus kas

$$
N P V=\mathrm{C} 0+P V r
$$

dimana :

NPV = Net Present Value

$\mathrm{C} 0 \quad$ = jumlah uang yang diinvestasikan pada awal masa proyek (tahun ke-0). Karena ini pengeluaran, maka menggunakan bilangan negatif 
Hal berikut menunjukan perhitungan $N P V$ terhadap keputusan investasi yang akan dilakukan.

$N P V>0$, Investasi yang dilakukan memberikan manfaat bagi perusahaan. Maka proyek bisa dijalankan.

$N P V=0$, Investasi yang dilakukan tidak membuat perusahaan rugi maupun untung. Sehingga, Kalau proyek dilaksanakan atau tidak dilaksanakan tidak akan berpengaruh pada keuangan perusahaan. Keputusan harus ditetapkan dengan menggunakan kriteria lain misalnya dengan dampak investasi terhadap positioning perusahaan

$N P V<0$, Investasi yang dilakukan akan mengakibatkan kerugian bagi perusahaan maka proyek ditolak.

\section{HASIL DAN PEMBAHASAN}

\section{Analisis teknis desain lampu PJU panel surya}

Data Desain Lampu PJU Panel Surya diambil dari spesifikasi teknis komponen yang digunakan. Untuk menganalisis desain lampu PJU, maka perhitungan dilakukan dari beban menuju sumber energi. Beban yang digunakan pada desain Lampu PJU Panel Surya adalah Lampu LED, 40 W DC, dengan faktor daya 0,91.

Hubungan antara daya nyata, tegangan dan arus dinyatakan oleh Mismail (1981) $\mathrm{P}=\mathrm{VI} \cos \varphi$, dimana:

$\mathrm{P}=$ Daya nyata (Watt)

$\mathrm{V}=$ Tegangan (Volt)

$\mathrm{I}=$ Arus (Ampere), dan

$\cos \varphi=$ faktor daya

Lampu/beban akan menyala apabila diberikan daya yang bersumber dari baterai. Daya baterai adalah daya nyata yang memiliki satuan VA. Daya baterai terpasang minimal adalah:

$\mathrm{VI} \quad=\mathrm{P} / \cos \varphi \mathrm{VA}$

$=40 / 0.91 \mathrm{VA}$

$=43.96 \mathrm{VA}$.

Baterai tersebut harus dapat memberikan daya sebesar 43,96 VA dalam jangka waktu minimal 12 jam, maka kapasitas minimal baterai adalah

VIhour $=43,96 \times 12 \mathrm{VAh}$

$=527.52 \mathrm{VAh}$

Diketahui bahwa spesifikasi teknis baterai adalah $12.8 \mathrm{~V}, 50 \mathrm{Ah}$, sehingga kapasitasnya secara perhitungan teknis

VIhour baterai $=12.8 \times 50 \mathrm{VAh}$

$=640 \mathrm{VAh}$

Dengan evaluasi desain tersebut, kapasitas baterai lebih besar dari kapasitas minimal baterai yang diperlukan untuk menyalakan lampu $40 \mathrm{~W}$ DC selama 12 jam. Baterai memberikan daya kepada lampu selama 12 jam pada malam hari. Selama lampu tidak menyala pada siang hari, maka baterai akan diisi dayanya dari energy yang dibangkitkan oleh panel surya. Yuliarto (2017) menyebutkan bahwa kehilangan daya dari energi yang dihasilkan panel surya adalah sebesar 30\% dan di Indonesia asumsi penyinaran matahari pada waktu optimum untuk menghasilkan listrik adalah 5 jam per hari. Jika kapasitas minimum baterai yang dibutuhkan 527.52 VAh, dengan asumsi daya yang hilang 30\%, maka daya yang harus dihasilkan oleh panel surya adalah $1.3 \times 527.52=685.78$ VAh. Dengan asumsi penyinaran per hari 5 jam, maka panel surya yang diperlukan minimal adalah $685.78 / 5=137.16 \mathrm{VA}$. 
Sesuai spesifikasi teknis, panel surya yang dipasang adalah $150 \mathrm{WP}$, artinya memiliki kapasitas lebih tinggi dari yang diperlukan, yaitu 137.16 VA. Dengan demikian, secara perhitungan, desain lampu PJU ini dapat bekerja memenuhi kebutuhan untuk menyalakan lampu selama 12 jam di waktu malam, dan panel surya dapat mengisi baterai di waktu siang. Berdasarkan data server Epever, yang dapat diunduh secara online melalui aplikasi Epever, maka sebagai contoh diperoleh data untuk lampu 1 dari tanggal 20 September 2018 sampai dengan tanggal 26-09-2018. Seperti disajikan pada Gambar 2.
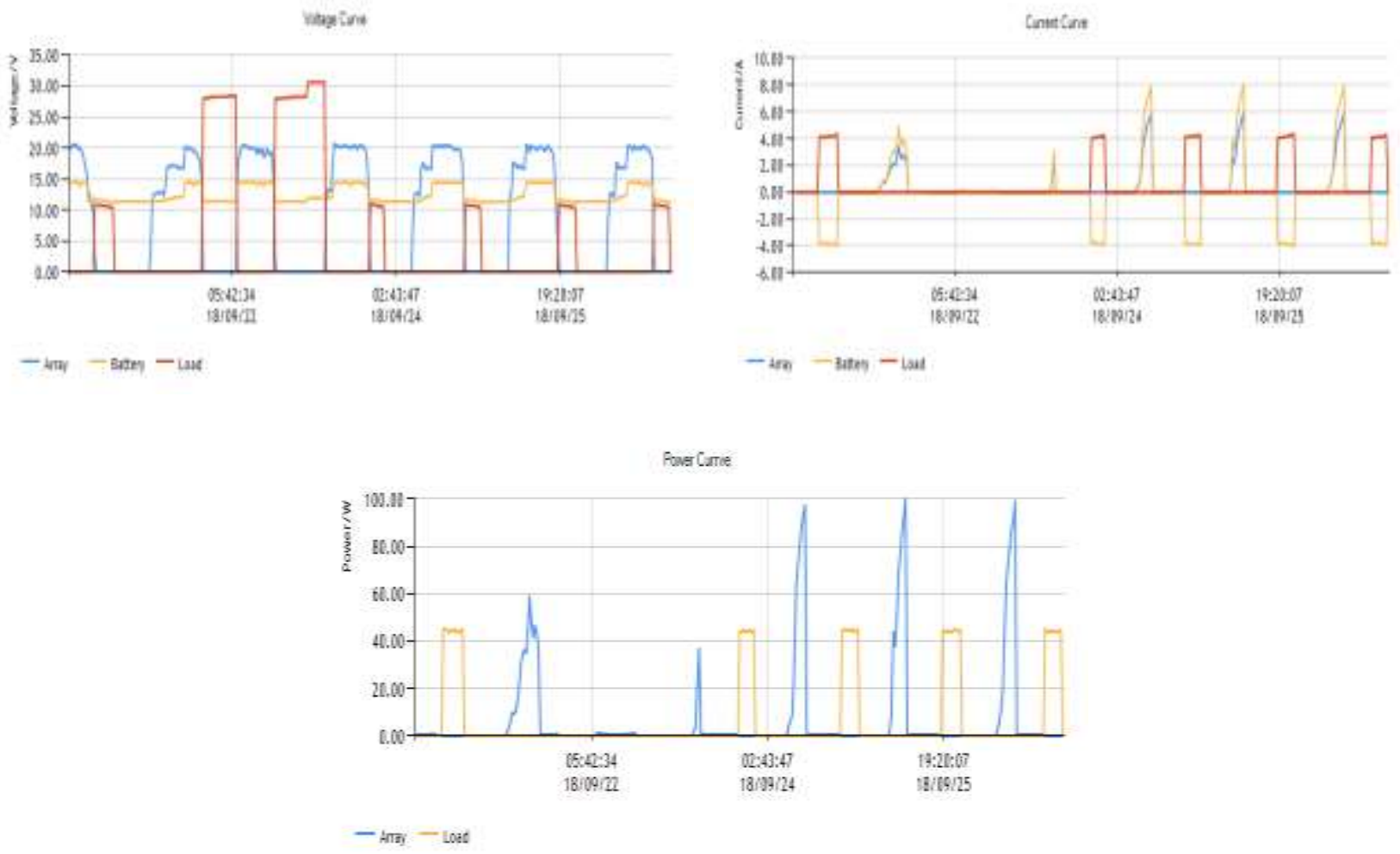

Gambar 2 Grafik Tegangan, Arus dan Daya pada titik 1.

Gambar 2 menjelaskan hal bahwa awal pemasangan, tanggal 20 September 2018, baterai telah diisi di pabrikan, sehingga walaupun terdapat tegangan pada array (panel surya), namun tidak terjadi pengisian pada beterai. Pada pukul 18.40, terjadi discharge pada baterai, yang mengalirkan arus dari baterai ke lampu. Proses discharge berlangsung sampai dengan pukul 22.40 .

Pada tanggal 21 sampai dengan 23 September 2018, beban lampu dilepas, hal ini untuk menguji proses pengisian baterai dari panel surya, Status lampu mati, Status baterai, terdapat tegangan pada baterai, dan baterai diisi dari panel surya (array). Status Panel Surya, terdapat tegangan pada dan arus panel surya yang mengalir dari panel surya ke baterai, hal ini berarti ada proses pengisian pada baterai.

Pada tanggal 24 September 2018, lampu kembali disambungkan. Status lampu menyala pada pukul 19.01 dan mati pada pukul 22.43. Status baterai, terdapat tegangan pada baterai, dan baterai telah diisi dari Panel Surya/Array. Pada pukul 19.01, terjadi discharge pada baterai, yang mengalirkan arus dari baterai ke lampu. Proses discharge berlangsung sampai dengan pukul 22.43. Proses ini berulang hingga tanggal 26 September 2018 dengan pola yang relatif sama.

Grafik pada Gambar 2 menunjukan besarnya tegangan dan arus listrik yang mengalir pada lampu telah sesuai dengan spesifikasi teknis lampu, begitu pula untuk baterai dan panel surya (array). Namun, lamanya lampu menyala tidak sesuai dengan harapan, yaitu selama 12 jam. Sesuai grafik, hal ini terjadi karena suplai daya dari baterai tidak mencukupi untuk lampu menyala selama 12 jam. 
Panel Surya terlihat dapat memberikan suplai daya sampai dengan baterai terisi penuh. Dari grafik Gambar 2 terlihat bahwa saat panel surya masih dapat menyuplai daya, namun baterai tidak lagi terisi dikarenakan sudah penuh. Dengan demikian permasalahan sistem PJU ini terdapat pada baterai terpasang. Membandingkan antara kapasitas baterai terpasang dengan kapasitas baterai yang direncanakan, dapat dilakukan sebagai berikut:

Spesifikasi kapasitas baterai yang direncanakan adalah $60 \mathrm{Ah}, 12.8 \mathrm{~V}$, sehingga kapasitas energi baterai adalah $60 \mathrm{Ah} \times 12.8 \mathrm{~V}=768 \mathrm{VAh}$. Beban lampu terpasang dengan faktor daya 0.91 adalah 40W atau 40/0.91 $=43.96 \mathrm{VA}$. Maka seharusnya baterai tersebut dapat menyuplai daya selama 768/43.96 = 17.47 jam. Kemampuan panel surya menurut spesifikasi teknis adalah $=150 \mathrm{Wp}$.

Dari Gambar 2 juga diketahui bahwa lama penyinaran puncak lebih dari 5 jam, sementara itu menurut Yuliarto (2017) dengan menganggap lama penyinaran adalah 5 jam, maka energi yang dihasilkan adalah $5 \mathrm{x}$ $150 \mathrm{Wh}=750 \mathrm{Wh}$. Dengan menghitung faktor loses energy sebesar $30 \%$, maka energy yang dihasilkan adalah $750 / 1.3 \mathrm{Wh}=576.92 \mathrm{Wh}$ atau 633.98VAh. Dengan tegangan sebesar $12.8 \mathrm{~V}$, maka panel surya dapat menyuplai baterai sebesar 633.98/12, $8=49.53 \mathrm{Ah}$ atau dapat menyalakan lampu selama 633.98/43.96 $=14.42$ jam.

Kapasitas baterai terpasang dapat dihitung dari data yang ada, dengan cara menghitung arus dan tegangan rata-rata baterai saat menyuplai lampu. Contoh hasil perhitungan kapasitas baterai terpasang dengan waktu lampu menyala untuk baterai 1 adalah 14.16 Ah seperti pada Tabel 1.

Tabel 1 Hasil perhitungan kapasitas baterai pada masing-masing titik.

\begin{tabular}{lccccc}
\hline \multicolumn{2}{c}{ Komponen } & $\mathrm{I}_{\text {rata-rata }}(\mathrm{A})$ & $\mathrm{V}_{\text {rata-rata }}(\mathrm{V})$ & Lama waktu lampu menyala & Kapasitas Baterai $(\mathrm{Ah})$ \\
\hline Baterai & 1 & 3.86 & 11.49 & 3 jam 31 menit & 13.57 \\
Baterai & 2 & 3.73 & 11.60 & 7 jam 43 menit & 28.78 \\
Baterai & 3 & 3.83 & 11.60 & 7 jam 27 menit & 28.53 \\
Baterai & 4 & 3.78 & 11.49 & 5 jam 03 menit & 19.09 \\
Baterai & 5 & 3.86 & 11.45 & 3 jam 35 menit & 13.83 \\
Baterai & 6 & 3.71 & 11.62 & 7 jam 58 menit & 29.56 \\
Baterai & 7 & 3.82 & 11.60 & 7 jam 27 menit & 28.46 \\
Baterai & 8 & 3.79 & 11.45 & 3 jam 04 menit & 11.62 \\
Baterai & 9 & 3.86 & 11.56 & 7 jam 03 menit & 27.21 \\
Baterai & 10 & 3.83 & 11.60 & 8 jam 03 menit & 30.83 \\
Baterai & 11 & 3.87 & 11.52 & 3 jam 44 menit & 14.45 \\
\hline
\end{tabular}

Data pada tabel 1 menunjukkan bahwa dari seluruh baterai yang ada, tidak memenuhi spesifikasi teknis baterai yang telah ditentukan, yaitu $50 \mathrm{Ah}$. Dengan demikian waktu menyala lampu tidak sesuai yang diharapkan, yaitu selama 12 jam, untuk itu harus dilakukan penggantian baterai sesuai spesifikasi teknis yang telah ditentukan.

\section{Hasil Analisis Ekonomis}

Analisis ekonomis dilakukan dengan menghitung berdasarkan desain lampu PJU yang dibuat. Umur investasi adalah 25 tahun, sesuai umur panel Surya. Umur investasi 1 buah baterai adalah 2000 cycles DOD, artinya baterai dapat digunakan isi ulang selama 2000 kali. Jika satu hari baterai diisi ulang satu kali, maka satu buah baterai dapat digunakan selama 2000/365 $=5.48$ tahun. Karena umur investasi adalah 25 tahun, maka baterai yang dibutuhkan adalah $25 / 5.48=4.56$ buah baterai atau 5 buah baterai.

Umur investasi 1 buah lampu adalah 50000 jam kerja. Dalam satu hari, lampu bekerja selama 12 jam, maka lampu dapat digunakan selama 50 000: $(12 \times 365)=11.42$ tahun. Karena umur investasi adalah 25 tahun, maka jumlah lampu yang dibutuhkan adalah $25 / 11.42=2.19$ buah lampu per titik atau 3 buah lampu. Biaya investasi didapatkan dari hasil perhitungan adalah sebagaimana ditunjukkan oleh Tabel 2. 
Tabel 2 Hasil perhitungan biaya investasi.

\begin{tabular}{llccrr}
\hline No & Komponen & Vol & Satuan & Harga satuan (Rp.) & \multicolumn{1}{c}{ Jumlah (Rp.) } \\
\hline 1 & Panel Surya & 1 & Buah & 2450000 & 2450000 \\
2 & SCC & 1 & Buah & 3330000 & 3330000 \\
3 & Smart Modular & 1 & Buah & 2990000 & 2990000 \\
4 & Baterai & 5 & Buah & 6037500 & 30187500 \\
5 & Lampu & 3 & Buah & 3440000 & 10320000 \\
$6 \quad$ Tiang dan instalasi & 1 & Buah & 2800000 & 2800000 \\
Jumlah & & & & 52077500 \\
$\quad$ Untuk 11 titik & & & & 572852500 \\
$\quad$ Gateway & & & & 3120000 \\
$\quad$ Komunikasi data @50 rb/bulan & 300 & Bulan & 50000 & $15,000,000$ \\
Jumlah Total & & & & 590972500 \\
\hline
\end{tabular}

Data Tabel 2 menunjukkan bahwa pada tahun ke-25, baterai dan lampu masih memiliki nilai sisa investasi. Kemampuan umur baterai adalah 2000 cycles DOD per buah sehingga 5 buah baterai menghasilkan 5 x 2000 $=10000$ cycles. Pengisian ulang baterai selama 25 tahun adalah $25 \times 365=9125$ hari atau 9125 kali isi ulang. Kapasitas sisa baterai adalah $10000-9125$ cycles $=875$ cycles. Nilai sisa baterai adalah $875 / 2000 \times$ Rp. 6 037500 x 11 titik = Rp. 29055 468. Perhitungan untuk lampu dilakukan dengan kemampuan umur lampu adalah 50,000 jam per buah. Penggunaan lampu sebanyak 3 buah menghasilkan $50000 \times 3=150000$ jam. Penggunaan lampu selama 25 tahun dimana setiap hari lampu menyala 12 jam $=25 \times 365$ x $12=109500$ jam. Kapasitas sisa lampu adalah 150 000-109 $500=40500$ jam. Nilai sisa lampu adalah $40500 / 50000$ x Rp. 3 340000 x $11=$ Rp. 30640400.

Nilai sisa baterai pada tahun ke-25, dengan memperhitungkan diskon rate 10\% adalah Rp. 2827986 sedangkan nilai sisa lampu pada tahun ke-25, dengan memperhitungkan diskon rate $10 \%$ adalah Rp. 2861 703. Perhitungan untuk pendapatan dengan memperoleh lisrik dari lampu PJU dengan mengalikan harga per Kwh listrik non-subsidi. Beban lampu $40 \mathrm{~W}$ yang menyala selama 12 jam, maka dalam satu tahun, 1 titik lampu akan menghasilan energi sebesar:

$$
\begin{aligned}
\text { Produksi Kwh } & =(40 \mathrm{~W} \times 12 \mathrm{jam} \times 365 \text { hari }) / 1000 \mathrm{KWh} \\
& =175.2 \mathrm{KWh}
\end{aligned}
$$

Produksi KWh 11 titik $=175.2 \times 11$

$$
=1927.2 \mathrm{KWh}
$$

Harga listrik non Subsidi PLN adalah Rp. 1647 /KWh

Pendapatan per tahun adalah $=$ Rp. 1647 x 1927.2

$$
\text { =Rp. } 3174098
$$

Langkah selanjutnya adalah melakukan perhitungan NPV. Diskon rate (i) ditentukan $=10 \%$, maka diperoleh hasil perhitungan sebagaimana ditunjukkan pada Tabel 3.

Tabel 3 Hasil Perhitungan NPV untuk pendapatan KWh dengan diskon rate 10\%

\begin{tabular}{rlrrr}
\hline No & \multicolumn{1}{c}{ Keterangan } & Aliran Kas (Rt) & \multicolumn{2}{c}{$\mathrm{Rt} /(1+\mathrm{i})^{\mathrm{t}}$} \\
\hline 1 & Pendapatan tahun ke & 1 & 3174098 & 2885544 \\
2 & Pendapatan tahun ke & 2 & 3174098 & 2623221 \\
$\ldots$ & Pendapatan tahun ke & $\ldots$ & $\ldots$ & $\ldots \ldots$ \\
25 & Pendapatan tahun ke & 25 & 3174098 & 292956 \\
\multicolumn{2}{r}{ Total pendapatan KWh selama 25 tahun } & & 28811418 \\
\hline
\end{tabular}




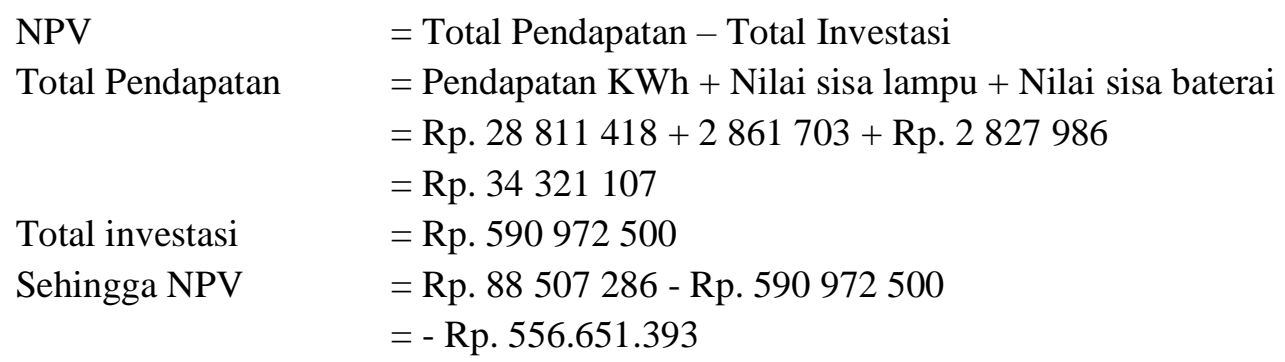

Jika diskon rate (i) ditentukan sebesar 0\%, maka diperoleh hasil perhitungan sebagaimana ditunjukkan pada Tabel 4.

Tabel 4 Hasil Perhitungan NPV untuk Pendapatan KWh dengan Diskon Rate 0\%.

\begin{tabular}{clrrr}
\hline No & Keterangan & & Aliran Kas (Rt) & \multicolumn{1}{c}{ Rt $/(1+\mathrm{i})^{\mathrm{t}}$} \\
\hline 1 & Pendapatan tahun ke & 1 & 3174098 & 3174098 \\
2 & Pendapatan tahun ke & 2 & 3174098 & 3174098 \\
$\ldots$ & Pendapatan tahun ke & $\ldots$ & $\ldots$ & $\ldots \ldots$ \\
25 & Pendapatan tahun ke & 25 & 3174098 & 3174098 \\
& Total pendapatan KWh selama 25 tahun & & 79352460 \\
\hline
\end{tabular}

$\begin{array}{ll}\text { NPV } & =\text { Total Pendapatan }- \text { Total Investasi } \\ \text { Total Pendapatan } & =\text { Pendapatan KWh + Nilai sisa lampu + Nilai sisa baterai } \\ & =\text { Rp. } 79352460+29055468+\text { Rp. } 30640400 \\ & =\text { Rp. } 139048328 \\ \text { Total investasi } & =\text { Rp. } 590972500 \\ \text { Sehingga NPV } & =\text { Rp. } 139048328-\text { Rp. } 590972500 \\ & =- \text { Rp. } 451924172\end{array}$

Kelayakan ekonomis PJU Panel Surya dapat dicapai dengan menghitung Kwh yang dihasilkan. Diskon rate ditentukan $0 \%$, maka perhitungan harga Kwh adalah sebagai berikut:

$\mathrm{NPV}=0$

Total Pendapatan - Total Investasi $=0$

Total Pendapatan $=$ Total Investasi

Pendapatan KWh + Nilai sisa lampu + Nilai sisa baterai $=$ Total Investasi

Pendapatan KWh $=$ Total Investasi - Nilai sisa lampu - Nilai sisa baterai

Pendapatan KWh = Rp. 590972500 - 29055468 - Rp. 30640400

Pendapatan KWh = Rp. 531276632

Diskon rate (i) ditentukan 0\%, maka dengan umur investasi 25 tahun.

Pendapatan KWh per tahun = Rp. 531276 632/25 = Rp. 21251066

dengan produksi listrik per tahun $1927.2 \mathrm{KWh}$

harga keekonomisan listrik PJU Solar Panel per Kwh = Rp. 21251 066/ 1927.2

$=$ Rp. 11027

Hal ini dapat dijelaskan, bahwa pemasangan lampu PJU bukanlah suatu proyek investasi yang layak secara bisnis dilakukan pihak swasta. Kelayakan secara ekonomis diperoleh jika harga listrik per Kwh mencapai nilai Rp. 11.027.

Meskipun secara ekonomis tidak menguntungkan, namun bila dibandingkan dengan sumber listrik PLN, pemasangan PJU Panel Surya lebih menguntungkan dari sisi energi baru terbarukan. 


\section{SIMPULAN}

Berdasarkan hasil penelitian yang dilakukan, diperoleh simpulan sebagai berikut: 1)Desain Lampu PJU Panel Surya menggunakan komponen Panel Surya merk Jembo PV, tipe 150P dan Lampu LED merk Solarens tipe SL020-MT serta Baterai Lithium merk JYV tipe LFPxx. Komponen Panel Surya dan Lampu bekerja sesuai spesifikasi teknisnya, sedangkan Baterai tidak bekerja sesuai spesifikasi teknisnya, waktu lampu menyala kurang dari yang telah ditetapkan, yaitu kurang dari $12 \mathrm{Jam}$, 2) Status hidup atau mati lampu dan kondisi komponen (panel surya, lampu dan baterai) Lampu PJU Panel Surya dapat dilakukan secara terpusat, melalui Komputer PC/Laptop menggunakan aplikasi Epever. Pemantauan dilakukan dengan melihat data teknis berupa tegangan, arus dan daya secara real time, dan 3)Nilai NPV dengan diskon rate $10 \%$ menunjukkan Pemasangan lampu PJU tidak layak untuk bisnis. Perhitungan diskon rate 0\%, kelayakan secara ekonomis diperoleh jika harga listrik per Kwh mencapai nilai Rp. 11.027, sekitar tujuh kali harga listrik PLN per KWh tanpa subsidi.

\section{DAFTAR PUSTAKA}

Bukvic M, Janjic R, Stojanovic B. 2017. Recycling Lithium-Ion Battery. [Internet]. [diunduh 2018 Oktober 14]. Tersedia pada https://www.researchgate.net/publication/321483410_RECYCLING_LITHIUMION_BATTERY.

Direktorat Jenderal Ketenagalistrikan. Statistik Ketenagalistrikan. 2016. Jakarta (ID): Kementerian Energi dan Sumber Daya Mineral.

Gouthami C, Santosh C, Kumar AP, Karthik A, Ramya KR. 2016. Design and Implementation of Automatic Street Light Control System using Light Dependent Resistor. International Journal of Engineering Trends and Technology (IJETT). 35(10).

Harten P Van, Setiawan E. 1995. Instalasi Listrik Arus Kuat 2. Bandung (ID): Binacipta.

Ibrahim Y. 2003. Studi Kelayakan Bisnis. Jakarta (ID): Rineka Cipta.

Iorkyaa A, Richard Ar I, Amah AN. 2012.The Efficacy of Light Emitting Diode (LED) Lamps Used in Rural Communities of Nigeria. Journal Energy and Environment Research. 2.

Irawan FA, Dhofir M, Suyono H. 2013. Analisis Peningkatan efisiensi penerangan jalan umum di Kabupaten Jember [Internet]. [diunduh pada 2018 Juni 5]. Tersedia pada http://jurnal.untan.ac.id/index.php/jteuntan/article/view/8793/8757.

Kadir A. 1995. Energi Sumber Daya, Inovasi, Tenaga Listrik dan Potensi Ekonomi. Jakarta (ID): Penerbit Universitas Indonesia.

Kasmir, Jakfar. 2003. Studi Kelayakan Bisnis. Jakarta (ID): Kencana.

Khwee KK. 2013. Pengaruh temperatur terhadap kapasitas daya panel surya (Studi Kasus: Pontianak). Jurnal ELKHA. 5(2): 23-25.

Kosaraju S. tanpa tahun. A Review of 'The Importance of Recycling Lithium-Ion Batteries for Lithium, in Vieuw of Impeding Electric Vehicle Industry'. [Internet]. [diunduh 2018 Oktober 14]. Tersedia pada https://pdfs.semanticscholar.org/6aac/130904896e41a7aafd3ff02283e0f02cf5b6.pdf.

Kushnir D. 2015. Lithium Ion Battery Recycling Technology [Internet]. [diunduh 2018 Oktober 14]. Tersedia pada http://publications.lib.chalmers.se/records/fulltext/230991/local_230991.pdf.

Mardikaningsih IS, Sutopo W, Astuti RW. Studi Kasus Analisis Teknis dan Ekonomis Penerapan Penerangan Jalan Umum Bertenaga Sel Surya [Internet]. [diunduh pada 2018 Juni 5]. Tersedia pada http://idec.industri.ft.uns.ac.id/wp-content/uploads/2017/11/Prosiding2016_ID048.pdf.

Mismail B. 1981. Rangkaian Listrik Jilid Pertama. Malang (ID): PT AAA Tridaya.

Moenir HAS. 2002. Manajemen Pelayanan Umum di Indonesia. Jakarta (ID): Bumi Aksara. 
Mudiarso D. 2003. Sepuluh Tahun Perjalanan Negosiasi Konvensi Perubahan Iklim. Jakarta (ID): Penerbit buku Kompas.

Napitupulu RAM. 2017. Pengaruh Material Monokristal dan Polikristal terhadap karakteristik Panel Surya 20 WP. Jurnal Poliprofesi. 7(1): 61-67.

Nasution AH. 2006. Manajemen Industri. Yogyakarta (ID): Penerbit Andi.

Rahman A. 2016. Lithium Battery Recycling Management and Policy, Int. J. Energi Technology and Policy, [Internet]. [diunduh $2018 \quad$ Oktober 14$]. \quad$ Tersedia pada https://www.researchgate.net/publication/308063762_Lithium_Battery_Recycling_Management_and_ Policy.

Rojas M, Zea H. 2016. Characterization and Recycling Procedure of Spent Lithium Ion Batteries from Mobile Phones, Australian Journal of Basic and Applied Sciences. [Internet]. [diunduh 2018 Oktober 14]. Tersedia pada http://www.ajbasweb.com/old/ajbas/2016/Octoper/140-147.pdf.

Rout MK, Meher S, Dhar J, Sahu Y, Das S. 2016. Design of Modern Solar Street Light Intensity Controller: An Energi Saving Approach. [Internet]. [diunduh 2018 Oktober 14]. Tersedia pada https://www.researchgate.net/profile/Yashraj_Sahu2/publication/297739074_Design_of_Modern_Sola r_Street_Light_Intensity_Controller_An_Energi_Saving_Approach/links/56e2a65fo8ae-4e3e9429df5c/ Design-of-Modern-Solar-Street-Light-Intensity-Controller-An-Energi-SavingApproach.pdf?origin=publication_detail.

Saleem AL, Sagar RR, Datta NS, Sachin HS. 2015. Street light monitoring and control system. International Journal of Engineering and Techniques. 1(2).

Sapiie S, Nishino O. 1994. Pengukuran dan Alat-alat Ukur Listrik. Jakarta(ID): PT Pradnya Paramita.

Sihombing DTB. 2013. Perencanaan Sistem Penerangan Jalan Umum dan Taman di Areal Kampus USU dengan menggunakan Teknologi Tenaga Surya (Aplikasi Pendopo dan Lapangan Parkir). Medan (ID): Teknik Elektro USU.

Siregar HB. 2015. Ekonomi Teknik. Yogyakarta (ID): Graha Ilmu.

Standard Nasional Indonesia 7391:2008. 2008. Spesifikasi Penerangan Jalan di Kawasan Perkotaan. Jakarta (ID): Badan Standardisasi Nasional.

Sudibyo H, Arum A, Gde Dharma A, Wibisono G. 2015. Rancang bangun sistem lampu jalan pintar nirkabel berbasis teknologi zigbee. Jurnal TESLA, 17(1): 45-51.

Sulisyanto. 2010. Studi Kelayakan Bisnis. Yogyakarta (ID): Penerbit Andi.

Suwandi A, Fardian F. 2016. Analisis Pemakaian Lampu LED terhadap Energi dan Efisiensi Biaya di PT Total Bangun Persada TBK. [Internet]. [diunduh pada 2018 Juni 5]. Tersedia pada http://journal.unisla.ac.id/pdf/110122016/jurnal4.pdf.

Utomo YS. 2015. Uji Kinerja Baterai Deep Cycle pada Sistem Pembangkit Listrik Tenaga Surya Photovoltaik, Jurnal Material dan Energi Indonesia [Internet]. [diunduh pada 2018 Juni 5]. Tersedia pada http://lipi.go.id/publikasi/uji-kinerja-baterai-deep-cycle-pada-sistem-pembangkit-listrik-tenagasurya-photovoltaik/7680.

Wen TS, Jia SL. 2013. Design and implementation of a smart LED lighting system using a self adaptive weighted data fusion algorithm. Journal Sensors, [Internet]. [diunduh 2018 Oktober 14]. Tersedia pada https://www.google.com/url?sa=t\&rct=j\&q=\&esrc=s\&source=web\&cd=10\&cad=rja\&uact=8\&ved=2a hUKEwiWhOiz_oXeAhVbcCsKHYviCn4QFjAJegQIAhAC\&url=https\%3A\%2F\%2Fwww.mdpi.com \%2F1424-8220\%2F13\%2F12\%2F16915\%2Fpdf\&usg=AOvVaw1YbwLhT7Fn0z8oQqLYuDY0.

Yuliarto B. 2017. Memanen Matahari. Bandung (ID): Penerbit ITB. 